\title{
Establishment of Harmonious Ecological Culture in University Campus
}

\author{
Yanhua Liu \\ School of Marxism, Changchun University of Science and Technology \\ Changchun 130022, China \\ E-mail: liuyanhua@cust.edu.cn
}

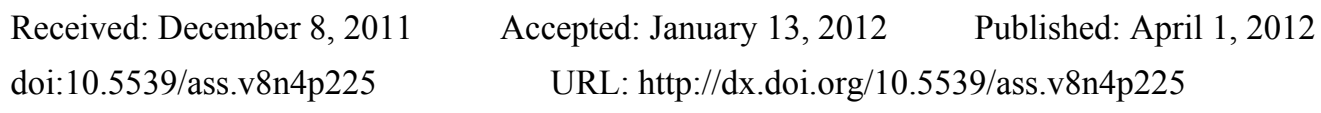

\begin{abstract}
Campus ecological culture is a sort of culture in which human kind gets along well in harmony with the natural environment. It represents the tide of evolvement of relationship between human kind and the natural environment, an important feature that universities are distinguished from other social organizations and an important foundation for sustainable development of universities. Campus ecological culture mainly includes ecologization of concept, ecologization of teaching, ecologization of management and ecologization of behavior. Establishment of campus ecological culture is the essential requirement to carry out the scientific outlook on development in an overall way, the realistic need to realize interpersonal harmony in university campus, an important approach for university students to develop in an overall and free way and a reliable guarantee for university students to survive and develop in a new century. Establishment of campus ecological culture has to insist on human orientation and realization of campus interpersonal harmony, has to carry forward the idea of freedom and realize academic harmony in university campus and has to strengthen environmental establishment and realize campus ecological harmony.
\end{abstract}

Keywords: Campus ecological culture, Harmony, Development

University is the cradle for growth of talents and is an important base for human culture to get extended and developed. As an important component of social culture, university campus culture influences and stimulates social culture with its high quality culture imbued with the flavor of the era and plays a demonstration and direction role in social culture, with strong cultural feedback function.

With reform and development of higher education, how to strengthen establishment of university campus culture is an important subject that higher education is faced up in a new century. Campus ecological culture is a brand-new campus culture and is a sort of culture in which human kind gets along well with the natural environment in a harmonious way. It represents the tide of evolvement of relationship between human kind and the natural environment and is an important foundation for sustainable development of universities.

\section{Basic connotation of campus ecological culture}

\subsection{Campus culture}

Campus culture refers to the particular campus life style that is formed under interaction of internal campus environment and external campus environment by all campus people. From the perspective of cultural pattern, the campus culture in its broad sense can be constituted by the following three patterns.

Campus material culture mainly refers to the material base to establish a campus, such as, campus environment, library data, scientific research equipment, broadcasting media, cultural facility and so on, and activities of concrete public culture, sanitation, sports and scientific practice that are held in the campus. Campus material culture is the hard environment in the campus culture and is the "first image" of the external part of a university.

Campus system culture mainly refers to the civilized and healthy living style, all sorts of rules and regulations, organizations and institutions and informal public groups as well as their functions in the campus and the school badge, school symbol, school song, school motto and so on. It is the basic feature and science of the times and the nation and sediment of the basic spirit of democracy in the campus, which reflects the holistic characteristics 
of campus culture.

Campus spiritual culture mainly refers to the concept of value, public opinions of the collective, cultural tradition, academic style and spiritual belief of teachers, students and school staff. It is the central aspect of campus culture, where the spirit of campus culture lies, and is also the point of strength for establishment of campus culture.

\subsection{Ecological culture}

Ecology is supposed to be a concept of biology. Today, ecological culture has broken through the concept of pure environmental science and has been extended to anthropology, sociology and even the entire field of humanities and social sciences. It is a culture in which human kind gets along well with the natural environment in a harmonious way and it represents the tide of evolvement of relationship between human kind and the natural environment.

From the perspective of evolvement of cultural development, it can be found that human being has gone through the natural culture of the remote antiquity and stepped over the humanity culture of the ancient society and is undergoing the scientific culture of the industrial civilization era. Around the 70s in the Twentieth Century, a new trend appeared in human culture --- ecological culture.

Emergence of ecological culture brought about revolution of human beings in the world outlook. That is to say, human beings replace the philosophy of "anthropocentrism" with the philosophy of respecting nature and reverence for life. Its emergence also makes the thinking mode of people from the mechanical theory to the holistic outlook of interaction and interassociation of things.

\subsection{Campus ecological culture}

Campus ecological culture refers to the sum of all material and spiritual wealth that is formed and created together by all teachers, students and school staff in the campus under the direction of the ecological value outlook. This is a new type of campus culture, an important feature that universities are distinguished from all other social organizations and an important base and inexhaustible motive force for an university to survive and develop.

In universities, campus ecological culture has two obvious characteristics. The first one is that it is imbued with exuberant and eternal life vitality. The major subjects in universities are young students who bring up cultural prosperity and who are full of youthful spirit; The second is their sustainability and harmony. The development of colleges and universities is the demand of social development and is the need of human progress. It depends upon mutual support, mutual benefit, co-existence and harmonious development of teachers, students and the environment.

The connotation of ecological culture on campus should mainly include ecologization of concept, ecologization of teaching, ecologization of management and ecologization of behavior. Ecologization of concept means that concepts of the teachers and students should come from harmonious development of human and the environment, and integrate cultivation of people into the ecological development of sustained harmony, coexistence and co-prosperity and realize unity of dialectical development of human and the environment. Ecologization of teaching means that teachers and students communicate with each other in the process of teaching in universities, complement with each other in the teaching, have diversified means, integrate arts with science, integrate different disciplines and are imbued with opening up and reform and innovation. Ecologization of management means that management personnel of university administrative management, student management, teaching management and logistics management have to look upon problems and analyze problems from the ecological viewpoint, treat with each ecological element in the educational system equally, follow the principle of ecological balance and incentive and competitive mechanism and deal with imparting, cognition, education and self-education in the process of education among teachers and students. Ecologization of behavior means that behaviors of universities, teachers and students have to reflect the concept of ecology and the norm of all behaviors is sustainable and harmonious development of the environment and human.

\section{Important significance of establishment of campus ecological culture}

\subsection{The essential requirement to carry out scientific outlook on development in an overall way}

The great progress of science and technology and the great improvement of social productivity have brought unprecedented wealth to the society and have accelerated the progress of civilization development. However, at the same time, such problems as excessive consumption of resources, serious pollution of the environment and imbalance of the natural ecology also increasingly prominent, which seriously poses threat to human survival and development. Humans become more and more aware that, the ecological environment is one of the core 
elements for the sustainable development of the society, and whether we develop economy at the expense of the environment or we develop science at the expense of humanity spirit, human beings will have to pay a heavy price for this.

University campus is the birth place and spreading place of the advanced culture and provides intelligence and cultural support for social development. colleges and universities should implement the scientific outlook on development, insist that each job in the school is developed in a comprehensive, coordinated and sustainable way, vigorously advocate building ecological culture on the campus, make due contributions to promoting the progress of the material civilization, spiritual civilization, political civilization and ecological civilization and bear due historical responsibility for improving the level of social productive forces and increasing the material wealth of the society that higher education is supposed to assume.

\subsection{The realistic need to realize interpersonal harmony of university campus}

Having walked into the 21st Century, human beings, on one hand, enjoy the well being that has been brought by high material civilization, and, on the other hand, suffer from the purgatory of contradiction of high spiritual culture. The shadow of the society once again is projected to the university campus. As a result, university is no longer a "pure land" and the "free communication of spirit" on the university campus no longer exists.

The reality tells us that in order to improve the quality of life of human beings, it is not only necessary to achieve harmony and intergrowth of human and the nature, but also necessary to attain harmony and co-existence of human and human.

An important aspect in construction of ecological culture on the campus is construction of a harmonious campus in which campus is the carrier and the main features are internal harmony and external success, everybody is in the same boat, logical administration and harmonious people co-exist and everything is in stability and in order. Studying, working and living in this big family, each one can experience the sense of achievement, sense of security and sense of belonging, which helps to form a healthy and progressive, stable and orderly environment in which everything is developed in harmony and everyone has a comfortable mood. Thus, it is the need for development of connotation of the school to establish the comprehensive, coordinated, free and sufficient development of school education and the ecological education theory of benign interaction and holistic optimization and to attempt to set up an interpersonal atmosphere of "human orientation and pursuit of human harmony". Besides, it is also the need to further deepen education and teaching reform, strengthen core competitive force of the school, enhance the cultural brand of the school and realize the target of school development.

\subsection{The important approach for overall and free development of university students}

Construction of ecological culture on the campus is an important battlefield to strengthen college students' ideological and political education. Campus ecological culture conveys the ideas, beliefs, world outlook, the outlook on life and values in concrete campus cultural activities that people are delighted to see and hear, which has particular and diversified functions of educating. By setting up a common value concept of the public, campus ecological culture forms an invisible centripetal force and cohesive force among young students and brings the behaviors of young students within a common ideal belief and value pursuit.

Ecological cultural construction on the campus is an extremely perfect stage to implement the quality oriented education among university students. In the process of designing campus ecological culture, participation of university students is indispensable. Here on the campus, the imagination space of students gets unlimited extension, their thinking of creation gets greatly developed and their comprehensive capacity gets fully exercised. Through the ecological cultural activities on the campus, not only the cooperative and competitive consciousness of students is cultivated, but also their artistic talent gets manifested, which makes students able to grow in a healthy direction in a happy education, context education and harmonious education.

Ecological cultural construction on the campus is helpful for intelligence development of university students. Worship of scientific spirit and establishment of academic innovation is the important content of ecological cultural construction on the campus. A variety of campus cultural activities that of profound academic atmosphere promote development of students' intelligence, capacity, innovative capacity and academic performance and cultivate students' hard working and plain living spirit, team cooperation consciousness and the capacity in applying the knowledge they have learnt in a comprehensive way.

Ecological cultural construction on the campus helps to improve personality of university students. Mo-tse said, "One will turn grey if died in grey and will turn yellow if died in yellow". The beautiful and clean campus, the colorful extracurricular life and the spiritual atmosphere that is full of youthful spirit all can purify the soul of 
university students, make their mentality get improved and their sentiment get edified. As a sort of potential recessive course, ecological culture on the campus is of great importance to cultivation of a perfect personality of university students.

\subsection{The reliable guarantee for survival and development of higher institutions of learning in a new century}

Construction of ecological culture on the campus helps to form a relaxed and good academic atmosphere. The value of existence of university lies in the fact it is the source of knowledge creation and the base of cultural dissemination. The sufficient academic freedom, fearless criticism on the tradition and brave exploration of the unknown world are the basic security for survival and development of university students. Thus, a relaxed and good academic atmosphere is of special significance to development of university students.

Construction of ecological culture on the campus helps to give full play to the creativity of teachers, students and staff. Creativity is the actual power and motive power source of school life and school survival and development and is the basic condition for coordinated development of education and social progress. This requires us to show respect for the vast majority of teachers' innovative spirit, acknowledge the individual differences of students and ensure that the enthusiasm and creativity of each school member is fully played and practically guaranteed.

Construction of ecological culture on the campus helps to form a stable and orderly campus environment. An important aspect of ecological campus is that the campus is in perfect order, the management order, teaching order and scientific research order of the school all present a continuous, coherent and stable operation state, each one who studies, works and lives on the campus is able to acquire personal and property security and guarantee, the campus structure stability and harmonious relationship are realized and the vast majority of teachers, students and staff are able to start an undertaking and pursue development in a peaceful way.

\section{Establishment of ecological culture on university campus}

\subsection{To insist on human orientation and to realize interpersonal harmony on the campus}

Ecological culture on the campus is the soil that is most suitable for life and growth of teachers and students. Construction of ecological culture on the campus has to insist on human orientation and has to adjust all sorts of relationships inside and outside the campus so as to form an ecological system that is developed in a coordinated way.

First of all, it is necessary to coordinate the relationship between competition and cooperation. We should both encourage competition and advocate cooperation. The contemporary society is developed swiftly and changing quickly, in which competition is more and more fierce and opportunities and challenges coexist. Competition should not be avoided and cooperation should not be ignored. Instead, both of the two are dialectical unity. Competition can stimulate potential and make people imbued with vitality and vigor, whereas cooperation is able to make the best of the both worlds, promote each other and strengthen the entire strength. A correct handling of relationships between the two can achieve the effect of mutual promotion and mutual improvement.

Then, it is necessary to coordinate relationship between teachers and students. Teachers and students ought to get along with each other in harmony, insist on personality equality and mutual respect, listen to all kinds of opinions with tolerance, fully reflect the profound humanistic care spirit, replace rigid planning and commanding with communication of soul and enable all positive elements to be extensively mobilized.

Finally, it is necessary to coordinate relationship between the school and teachers. The school ought to ensure that all sorts of reasonable interests of teachers can be attained and provide opportunities and conditions for intelligence and talents of teachers on the basis of respect, stimulation, care and development and create democratic and progressive atmosphere.

\subsection{To carry forward the thought of freedom and to realize academic harmony on the campus}

A great scholar is one who studies profound knowledge. Dissemination, criticism and exploration of knowledge is the eternal subject of university. University in a new century has to show obedience to the idea of academic freedom and be dedicated to establishment of a perfect academic ecology.

On one hand, university should put forth efforts to cultivate and create an academic atmosphere of worshiping academic knowledge, pursuing excellence and respecting education and innovation, change the campus to an academic palace of free spirit and create unlimited and free developmental space for excellent talents showing themselves. On the other hand, university has to pay attention to cultivating the rigorous learning attitude of teachers and students and their innovation working style, firmly set up self-esteem, self-discipline and the consciousness of cherishing academic reputation, scrupulously abide by academic morality and norm, strengthen 
cooperation and cultivate academic teams.

\subsection{To strengthen environmental construction and to realize ecological harmony on the campus}

"Resorting to mountains to enjoy human nature and resort to lake water to calm down". Perfect campus pattern, architectural style, beautification and greening as well as humanistic flavor implied in the environment are the silent carrier for educating and have unconscious influences upon edifying the sentiment of teachers and students, stimulating their intelligence and accumulating elegant campus culture. Therefore, the shape of university campus is supposed to have certain cultural color and educational consciousness and endow such buildings, facilities and environment as palace, building projects, flowers, plants and trees with rich connotation of ecological culture.

In the first place, in terms of planning of the architectural building clusters, it is necessary to fully reflect the scientific and artistic quality of the building, realize holistic harmony of the buildings, rationality of functions, modernization of facilities, convenience of use, environmental protection of materials and decent appearance and give full manifestation to the ecological and philosophical spirit of unity of nature and human.

Secondly, in terms of greening construction of the campus, we have to reflect the balance of ecological system and make the ecological system not only correspond with the aesthetical rule in appearance, but more consist with the ecological principle and biological features in terms of the holistic structure. Natural harmony should be achieved instead of preciosity.

Thirdly, we should reflect special characters and features of the school and let each corner of the school send out the glorious history and uncommon character of the university and the particular solemnness of the knowledge palace of higher education institutes and present the scientificalness, civilization and progress of the modern university at any time.

Finally, we should pay attention to the cultivation of the harmonious ecological humanity concept. We should cultivate, edify and even change the outlook on life, world outlook and ecological outlook of teachers and students and construct ecological civilization from the perspective of unity of ecological law (truth), ecological ethics (good) and ecological environment (beauty).

Universities in the 21 st Century are going towards the axis of the society. In face of the historical call, the university campus ought to insist on human orientation, carry out scientific outlook on development, enable the ecological culture to penetrate into the soul of the campus people, pursue harmonious development of human -education -- environment, create a new ground for campus ecological culture and propel sustainable development of modern universities.

\section{References}

Lin, Li. (2002). On Ecological Culture and Building of a New University Campus Culture. Education and Modernization, (3).

Liu, Chunhua. (2007). Construction of University Campus Culture in the Perspective of Cultural Ecology. Journal of Hunan University of Arts and Science, (9).

Liu, Yanhua. (2009). Considerations on the Construction of College Campus ECO-culture in 21st Century. Journal of Changchun University of Science and Technology (Social Sciences Edition), (6).

Qin, Yiming \& Wu, Wenliang. (2003). CAMPUS ECO- CULTURE. Higher Education Forum, (1).

Xiong, Qingnian. (2001). Campus Ecology and Ideas of Universities in a New Century. Exploration of University, (1). 